\title{
Competence and Professional Skills in Training Future Specialists in the Field of Physical Education and Sports
}

\section{Competencia y habilidades profesionales en la formación de futuros especialistas en el campo de la educación física y el deporte}

Ihor V. Ivanii*iD
Sumy State Pedagogical University named after A.S. Makarenko, Sumy, Ukraine.

ORCID: https://orcid.org/0000-0001-8245-1371

\section{Anton V. Vertel}

Sumy State Pedagogical University named after A.S. Makarenko, Sumy, Ukraine.

ORCID: https://orcid.org/0000-0003-2247-7443

\section{Nataliia M. Zlenko}

Sumy State Pedagogical University named after A.S. Makarenko, Sumy, Ukraine.

ORCID: https://orcid.org/0000-0003-2598-4336

\section{Vita H. Butenko}

Sumy State Pedagogical University named after A.S. Makarenko, Sumy, Ukraine. ORCID: https://orcid.org/0000-0002-3578-8147

\section{Oksana S. Biler}

Sumy State Pedagogical University named after A.S. Makarenko, Sumy, Ukraine. ORCID: https://orcid.org/0000-0001-9969-3289 oksbiler@tanu.pro

Received 02-12-20 Revised 03-13-20 Accepted 07-13-20 On line 08-29-20

*Correspondence

Email: iivanii1428@tanu.pro
Cite as:

Ivanii, I., Vertel, A., Zlenko, N., Butenko, V., \& Biler, S. (2020). Competence and Professional Skills in Training Future Specialists in the Field of Physical Education and Sports Propósitos y Representaciones, 8 (SPE2), e690. Doi: http://dx.doi.org/10.20511/pyr2020.v8nSPE2.690 


\section{Summary}

The relevance of the problem is determined by the need to understand the further strategy of improving the training of physical education and sports specialists. The purpose of the article is to study the problem of correlation between the notions of "competence" and "professional skill" in the context of the formation of a specialist in the field of physical education and sports. The study of the relationship between the notions of "competence" and "professional skill" was conducted on the basis of an array of special literature on the competent approach to training of physical education and sports specialists, including more than 200 sources published in different countries. The article analyses negative trends in the content of training future specialists in the system of higher professional physical education based on a competence approach. The acmeculturological approach for improving the professional training of future specialists is proposed and tested, the stages of formation of professional skills of future specialists in the training process are presented. There is a need to focus on the identified features of professional training of young people to professions in the field of physical education and sports. The proposed system of professional training of future specialists of physical education and sports on acme-culturological bases directs teachers to improve the quality of training graduates in their future professional activities.

Keywords: Physical Culture; Sport; Acme-Culturological Approach; Professional Suitability.

\section{Resumen}

La relevancia del problema está determinada por la necesidad de comprender la estrategia adicional de mejorar la capacitación de especialistas en educación física y deportes. El propósito del artículo es estudiar el problema de la correlación entre las nociones de "competencia" y "habilidad professional" en el contexto de la formación de un especialista en el campo de la educación física y el deporte. El estudio de la relación entre las nociones de "competencia" y "habilidad professional" se realizó sobre la base de una serie de literatura especial sobre el enfoque competente para la formación de especialistas en educación física y deportes, incluidas más de 200 fuentes publicadas en diferentes países. . El artículo analiza las tendencias negativas en el contenido de la formación de futuros especialistas en el sistema de educación física profesional superior basado en un enfoque de competencia. Se propone y prueba el enfoque acmeculturológico para mejorar la formación profesional de futuros especialistas, se presentan las etapas de formación de habilidades profesionales de futuros especialistas en el proceso de capacitación. Es necesario centrarse en las características identificadas de la formación profesional de los jóvenes para profesiones en el campo de la educación física y el deporte. El sistema propuesto de formación profesional de futuros especialistas en educación física y deportes sobre bases cultoculturales dirige a los docentes a mejorar la calidad de la formación de los graduados en sus futuras actividades profesionales.

Palabras clave: Cultura física; Deporte; Enfoque acmeculturológico; Idoneidad profesional.

\section{Introduction}

The modern paradigm developing in higher professional physical education is based on a competence approach. In recent years, the problem of improving the quality of physical education training has become acute in different countries (Zhamperisova \& Dosybayeva, 2010; Sobianin, 2002; Smolianinova, 2002; Enric \& Sebastiani, 2012). In this regard, the question arises - how effective this approach can be in the system of higher professional physical education, what are its prospects. To solve this question, it makes some sense to consider the relationship between the notions of "competence" and "professional skill" (Kuzmina, 2002; Dereka, 2017). The relevance 
of this question is that its solution is important for understanding the further strategy of improving the training of physical education and sports specialists. The purpose of this work is to study the problem of correlation between the notions of "competence" and "professional skill" in the context of the formation of a specialist in the field of physical education and sports.

In the analysis of the literature, however, theoretical readiness is largely highlighted in the essence of competence. For example, when discussing this notion, in one case it is said that competence has two components - content (knowledge) and procedural (skill), but in the end it is characterized by operational and mobile knowledge (Choshanov, 1997). Another paper states that competence is awareness (Rusova, 2002). At the same time, competence is widely represented in a number of documents, for example, in the "Concept of modernization of Russian education for the period up to 2020" (Mishin, 2003).

The purpose of the article is to study the problem of correlation between the notions of "competence" and "professional skill" in the context of the formation of a specialist in the field of physical education and sports.

\section{Methods}

The study of the problem of notions correlation of "competence" and "professional skill" was conducted on the basis of the relative competence approach to training specialists in the sphere of physical education and sport, explore the array of literature, including documents, textbooks, manuals, scientific articles, monographs, dissertations, proceedings of conferences and congresses. In total, more than 200 sources published in Ukraine, Russia, Kazakhstan, Slovakia, Moldova, Serbia and other countries were studied. To achieve the goal and solve the research tasks the following methods were used:

- theoretical: analysis, synthesis, comparison, content analysis of normative documents in the field of physical education and sport in order to determine the state of the developed problem of professional training of future specialists in physical education and sport based on the competence approach; corporate analysis - toestablish the significance and disadvantage of a lack of competence approach in the field of higher professional physical education; abstraction - to define criteria of quality results ofhigher professional physical education and ways to achieve the vertices (acme) in the future professional activity of specialists; classification, systematization and generalization - to study the problem of correlation of concepts "competence" and "professional skill" in the context of the formation of a specialist in the field of physical education and sport, as well as to define concepts "acmeology", "culture", "creative readiness", "professionalism", "teaching skills", "physical culture and sports" specialist; design in order to develop the concept of professional training of future specialists of physical education and sport on the acme-culturological foundations; modeling and generalization - to develop a system of professional training of future specialists of physical education and sport on the acmeculturological principles, establishing the stages of "movement" of the future specialist of physical education and sport from competence to professional physical education, as well as forming the conclusions of the study;

- empirical: observation, questioning, testing, expert evaluation and selfassessment of learning results - in order to test the effectiveness of the developed system of professional training of future specialists in physical education and sports on acme-culturological bases;

- $\quad$ statistical: methods of descriptive statistics, method of statistical hypotheses for qualitative evaluation of the results of innovations. 


\section{Results and discussion}

The essence of the problem, apparently, is in what it is meant by "professional competence" and how it is implemented in the practice of training specialists. In many dictionaries, "competence" is understood as "possessing competence" or "possessing knowledge that allows you to judge something". At the same time, a person who is "competent" is represented as (from the Latin "competens" - appropriate, capable) - "possessing competence" and "knowing, versed in the assigned area". Finally, the word "competence" (from Latin "competentia" - belonging by law) - means either "the terms of reference of some body or person" or "the range of issues in which this person has knowledge and experience" (Rogozhnikova, 1989; Landa, 1993). There are many other opinions about the essence of competence (Khytorskoy, 2006; Smolianinova, 2002; Rusova, 2002).

Analysis of these definitions of competence leads to the conclusion that:

- there is no clear interpretation of the essence of competence;

- $\quad$ competence is understood as a range of issues (possibly responsibilities, powers, etc.) that the person is responsible for;

- competence is understood as highly specialized awareness, theoretical training, knowledge of something;

- competence is understood both as the possession of knowledge in something, and as the possession of practical experience;

- competence is understood quite broadly, including knowledge, skills, abilities, personal qualities, and other components of a personality.

With the ambiguity of the interpretation of this term, it is not very clear what level of training of the specialist should be: either the specialist theoretically knows his duties, or he is ready both theoretically and practically to cope with the functions in his profession, or he simply knows the range of his duties in accordance with his position. Unfortunately, employers are not interested in this interpretation of the specialist in the conditions of tough competition in the labour market nowadays - professionalism is unconditionally required. Therefore, recently, in different areas of human activity, such expressions are widely used - "a professional", "professional".

How is the "competence" approach implemented in practice in the field of higher professional physical education? It is considered that it is implemented as a result of specialist training. At the same time, when mastering individual competencies in the content of education it is not taken into account whether a particular applicant is initially suitable for the profession or not. There are cases when a well-studied student actually turns out to be an unfit teacher in practice, and an inveterate "mediocre student" eventually becomes a good specialist. This phenomenon is due to the availability of professional aptitude for the profession.

Although the list of competencies contains requirements not only for knowledge, we have to state that the approach under consideration is mainly focused on the previous knowledge paradigm. This can be confirmed if in the content of state educational standards for training bachelors and masters in the field of physical culture to consider individual competencies and read other planning documents (Protocol to the Convention..., 1952). For example, in the conditions of Ukraine, the state educational standard of higher professional education in the field of training 01 "Education", 014 "Physical education", 017 "Physical education and sport" 
(qualification - master) provides lists of general cultural competencies (GC), professional competencies (PC), which in many cases are divorced from reality. It is clear that students will be able to master knowledge when passing certain subjects, but how to prepare future specialists so that they can, for example, "take responsibility for their decisions within the professional competence", "make non-standard decisions", "take initiative, including in situations of risk", "solve problem situations", etc. What is being done in higher education institutions in order to implement these competencies in reality? These competencies are quite in demand, beautifully formulated, but they are overstated, theorized and not implemented in reality.

Education becomes increasingly detached from the student's personality. The thesis about the humanization of education is declared, but in practice, the ill-considered introduction of computerization, testing, and distance learning further distance a teacher from a student. Without excluding the need for these trends, we should not forget that nothing can replace direct communication between a teacher and a student, no machine will improve the process of humanization without the human factor, direct communication, interaction. The best textbook, the best electronic program that appeared today, will become obsolete tomorrow. The teacher will always be able to convey to the student new ideas, facts, comprehensively explain the problematic aspects.

Another relevant issue in the training of a competent specialist is the increase in the relative share of independent work of students. In the general practice of higher education, this is an actual loss of educational time, since students of physical education specialties are more likely to spend their time training in chosen sport or satisfying their other interests than on self-study classes. Teachers do not actually organize independent work of students and its control. At the same time, students are not yet conscious enough to devote the necessary time to independent work.

The introduction of testing also does not correspond to the idea of humanizing education. In many subjects (for example, in special courses), it is very difficult to prepare test tasks in the proposed forms. A lot of useful information just does not "fit" into these forms. The teacher has to take information from other areas of knowledge, which distorts the content of the test and does not adequately reflect the subject itself. Students begin to understand that if they solve the test tasks correctly and "guess" some of the answers, they can get a positive mark. The teacher has less reason to carefully check the student, if the test is successful, the student and the teacher mutually release each other from further control, but the quality of theoretical readiness of students is reduced, because it is more difficult to answer questions orally or in writing, it is necessary to prepare for this more than just to answer test tasks, choosing the right answer option. In addition, testing does not require the student's creativity.

Another drawback of the modern competence approach in education is the "mosaic" readiness of students. The point is that previously, the curriculum for training physical education personnel in the academic budget allocated a large number of training hours for disciplines. Therefore, students thoroughly studied the academic disciplines. At present, the budget of educational hours has increased significantly, but there are more disciplines that are given little time and students do not have time not only to master the knowledge (there is no time for skills), but even the most general ideas about the essence of the discipline, or know the essence of the subjects, but very superficially. The problem of defragmentation of higher professional physical education has been long overdue (Gorelov et al., 2008). For this you need to substantiate how and in what sequence should be allocated a separate discipline, stages of learning, etc. Increasing educational information requires appropriate conditions, the use of more effective tools and methods of training. 
The contradiction to the idea of education humanization lies in the fact that neither teachers, nor curators, nor departments have objective information about what each individual student is (except for his success or failure in the session, attendance, sports achievements), have no idea about his abilities and inclinations in the chosen profession, do not engage in purposeful formation of professional motivation. At best, this happens spontaneously. The development of the system of professional physical education occurs as if by itself separately from the process of forming a specialist. Innovations are introduced into the content of higher education, but they are sometimes not perceived by students and even rejected. Students adapt to these innovations, trying to get out of the situation in different ways. For example, not so long ago in educational institutions, the majority of students passed final exams and only a few of the most prepared students defended their theses. According to the new requirements, all students must write final qualifying papers or dissertations, and this seems to be a useful innovation that corresponds to the dictates of the time. However, a significant number of students do not do this work on their own they either search for ready-made material on the Internet, or use the services of outsiders, including the teachers themselves.

Following the requirements of the competence approach, teachers of higher educational institutions fall under a harsh time limit that you have to spend on the development of the huge volume of planning documents, test items and other actions (which could do, for example, the Ministry or the educational-methodical association), but actually there are no time on the main activity - direct work with students. At the same time, more acutely raises the question about the quality of higher education, but here comes the confusion: evaluation of the quality of education in practice is reduced to the study of documentation on the departments, the evaluation of "residual knowledge" of students, but the actual quality of education remains without attention. After all, the main quality of the higher professional education system is "new formations in the personality" (Kuzmina, 2002).

According to professor N.V. Kuzmina (2002), the criterion for the quality of functioning of a higher professional physical education institution should be "creative readiness" for the upcoming professional activity. In order to achieve this result, it is necessary to reorient higher professional physical education on the acme-culturological approach, in order to present the achievement of the quality of education in accordance with the modern world in a new aspect. This approach is based on the consideration of all pedagogical categories in the light of the new educational paradigm. This is especially true for this type of education, which reflects the state of the culture type of society - "physical culture" (Dyba, 2015; Sobianin, 2002). In this case, the notions of "professionalism", "pedagogical skills", and "culture" should come to the first position. Culture is understood here as a specific, morally oriented way of human activity, as well as the evaluation and awareness of its results. At the same time, "competence" is not excluded from a number of relevant categories, but its status and place in the formation of a specialist change.

It is absolutely necessary to use as a starting point not only in theory, but also in the practice of training specialists in the field of physical culture the category that has long been known in labour psychology and engineering psychology - "professional suitability". "Professional suitability" is understood as a dynamic, relatively stable, optimal level of combination of biologically and socially determined human prerequisites necessary for successful professional activity in a particular field (Sobianin, 1998). Professional suitability for the activity of a specialist in the field of physical culture is "relative" by type, that is, it does not impose absolutely strict requirements on the future professional, since compensatory mechanisms play a major role in it, but requires the presence of separate components of professional suitability at a certain level. According to our data, the content of professional suitability of a specialist in the field of physical culture includes: professional-pedagogical orientation of the individual (interests, motives, ideals, value orientations, professional intentions, needs); mental suitability; physical suitability; individual-psychological characteristics of the individual (abilities, character, temperament) (Sobianin, 1991). 
Professional suitability is an initial category that must be taken into account at the preuniversity stage of forming a future specialist - during professional orientation and professional selection. This would significantly improve the quality of future physical education and teaching staff. Currently, unfortunately, it is not a professional selection, but a set of applicants without taking into account the professional suitability of candidates, which initially determines many problems that arise in the content of professional-pedagogical training in universities. At the same time, knowledge about the features of the student's professional suitability in the future during the period of study at the university could actually suggest an "individual way" of forming a specialist. Individual components of professional suitability could be adjusted through targeted pedagogical influence.

Further, on the basis of professional aptitude, "professional readiness" should be formed. We understand it as "professional competence" in a broad sense (that is, mainly theoretical readiness). In accordance with reality, a university graduate should be really competent, that is, ready for professional activity, but mostly theoretically - this moment fully corresponds to reality, because in fact, any graduate is not yet perfect in terms of professional skills, he simply does not have enough practice of professional activity. Adaptation to professional activity, as experience shows, lasts on average about 3-4 years. Even those who have already started to work in their specialty, while studying at the university, go through this period, because there comes a time when they compare what they learned in theory at the university with what exists in practice. In general, this stage does not contradict the modern paradigm of education - the training of a competent specialist, but brings a completely new meaning to this process, which consists in the fact that competence is not the final goal, but a passing stage in the preparation of a future professional specialist.

At the post-graduate stage of formation of a specialist, "professionalism" takes the first position in terms of its value (Daupaev \& Kuvashev, 2010). By professionalism, in contrast to the opinion of N.V. Kuzmina (2002), we understand skill in a broad sense. It is hardly to agree that "professionalism", as a "stable property of the person and activity of a specialist, is formed in the process of "professional education", because it takes time to achieve it after graduating from a higher education institution. The graduate, as a rule, is not quite ready for his work as a professional. He lacks practice, as it was mentioned above.

"Professionalism" is a skill that begins to be created on the basis of competence knowledge in a broad sense is melted down into a skill in a broad sense. Some authors replace this notion with a similar one, for example, "pedagogical skill", in which they consider the characteristics of a specialist's personality, his abilities, which begin to form a certain system (Vishibuti et al., 2004; Chokorilo, 1998). Gradually, the theoretical readiness of the specialist is updated in practice, everything superfluous, superficial, and not very necessary in reality disappears in it. On the other hand, the accumulated experience of activity is constantly correlated with theoretical knowledge, finds connections with the theory and merges with it. In professionalism, the future professional matures, who develops his own system of activity. This occurs in university graduates after adapting to professional and pedagogical activities for several years. At the same time, at this moment, specialists in the field of physical culture are moving towards their highest achievements in the profession, accumulate experience, and begin (consciously or unconsciously) to form the author's system of activity.

Finally, after a certain period of time, the specialist approaches his next stage of professional development. A "professional skill" is formed, this is a systemic property of the specialist's personality - which, based on the development of his professional suitability in the process of education and work, is formed into an individual (author's) skill that allows you to reach the top in teaching. However, not all specialists from "professionalism" reach a high level of "professional skill". This depends on many reasons. 
One of the main signs and results of the work of a master-teacher who reaches the top in the profession (acme) is the creation of an author's system of activity. According to the classification of V.P. Branskiy and S.D. Pozharskiy (2001), there are several variants of models for the appearance of acmes in professional activity. A single-peak model represents the achievement of only one peak (acme). The multi-peak model includes several peaks in the process of professional activity that are approximately the same in level and value in a certain period of time. The macro-peak model includes the "ladder" option, when the peaks gradually rise, then the moment of the highest peak comes, and then a gradual decrease in the peaks. There is, according to some authors, also a "bottomless" (that is, not falling down) model, which is a line that continuously rises to the maximum peak, ending on its rise up (Dereka, 2017). However, according to the data obtained in the research of academician N.V. Kuzmina (2002), the movement to the top in professional activity on the example of school teachers does not occur absolutely in the upward direction - all have short wave-like declines, combined with new rises. Probably, this pattern is related to the objective effect of various factors, including the factor of natural biological rhythms in human life.

The author's system created by a teacher is an established pedagogical system that has common features, but with a special specific handwriting and content that distinguishes this master from his colleagues. This uniqueness was previously formulated by G.G. Shakhverdov and G.F. Lesgaft (1950) in the expression: "The Method is me!". At the previous stages of selfpromotion to professional heights, the specialist creates only individual ideas and fragments of his future author's system. Getting a more perfect look, such a system passes a practical and theoretical test. When the author's system of professional activity becomes a recognized fact, the specialist usually already has certain distinctions, status, regalia, and awards that confirm his high professional level.

\section{Conclusions}

The study of the relationship between the notions of "competence" and "professional skill" of a specialist in physical education and sports shows that competence is primarily interpreted as a theoretical preparation of the individual, in contrast to professional skill, which is the ultimate goal of forming a specialist. Based on the above-mentioned information, competence has the right to be applied in higher education institutions, but should not be defined as the final result of the formation of future specialists in the field of physical culture and sports.

It is necessary to consider competence as the next stage of the specialist's movement to his professional skills. It is necessary to focus not only on the existing requirements of educational standards, but also on identifying the features of professional suitability of young people for professions in the field of physical culture and sports, its initial state and dynamics. Selection of applicants during admission to a higher education institution, it is necessary to focus the future specialist not only on acquiring knowledge and competencies, but also on the formation of professionalism, professional skill, and tops in professional activities in the field of physical culture and sports. Students must master the ways and means of mastering their chosen profession and reaching the top in professional activity. Preconditions for the formation of the future professional skill should be established on the basis of the idea of real humanization of the educational process, uncovering the potential of personality of students, formation of their culture.

\section{References}

Branskiy, V.P., Pozharskiy, S.D. (2001). Social synergetic and acmeology. St. Petersburg: Nauka. Chokorilo, R. (1998). Sport pedagogics. Belgrad: Vytcsha Shkola za Sportske Trenere.

Choshanov, M.A. (1997). Didactic design of flexible learning technology. Pedagogics, 2, 34-37.

Daupaev, M.O., Kuvashev, B.M. (2010). Pedagogical aspects of training of specialist of a physical culture and sport. Uralsk: WKSU Publishing House. 
Dereka, T.G. (2017). Acmeological principles of continuous professional training of specialists in physical education. Kyiv: Borys Grinchenko Kyiv University.

Dyba, T. (2015). Professional training of specialists of the competence lase. The Advanced Science Journal, 5, 99-102.

Enric, M., Sebastiani, I. (2012). Competence profile of physical education teachers. In: J. Vasickova, B. Antala (eds.), Professionals and Volunteers in Physical Education: Monograph Book of Scientific and Professional Articles, pp. 28-37. Bratislava: Slovart.

Gorelov, A.A., Gorelov, S.A., Rumba, O.G., Sokorev, V.V. (2008). About the necessity of defragmentation of maintenance of modern physical education. In: Strategy of Development of Sport for All and Legislative Bases of Physical Culture and Sport in the Countries of the CIS. Kishinev: USEFS.

Khytorskoy, A.V. (2006). Technology of projecting key and subject competences. Retrieved from: http://www.eidos.ru/younal/2006/0505htm

Kuzmina, N.V. (2002). Subject of acmeology. St. Petersburg: Politekhnika.

Landa, N.M. (1993). Modern dictionary of foreign words. Moscow: Russkiy Yazyk.

Mishin, B.I. (2003). Table book of a teacher of physical education. Moscow: Astrel.

Protocol to the Convention for the Protection of Human Rights and Fundamental Freedoms. (1952). Retrieved from: https://rm.coe.int/168006377c

Rogozhnikova, R.P. (1989). Dictionary of foreign words. Moscow: Russkiy Yazyk. Retrieved from: https://obuchalka.org/2015112987532/slovar-inostrannih-slov-1989.html

Rusova, N.Yu. (2002). Modern technologies in science and education. Nizhny Novgorod: LNSPU.

Shakhverdov, G.G. Lesgaft, P.F. (1950). Essay of life and scientifically-pedagogical activity. Leningrad: Nauka.

Smolianinova, O.G. (2002). Intelligent virtual reality software agents. Informatics and Education, 9, 45-50.

Sobianin, F.I. (1991). Professional-pedagogical suitability of students to activity of teacher of physical culture. Leningrad: Nauka.

Sobianin, F.I. (1998). Introduction to the acmeology teacher of physical culture. Shuya: SSPU.

Sobianin, F.I. (2002). Professional training of teachers of physical education on the basis of culturological approach. St. Petersburg: St. Petersburg State Academy of Physical Culture named after P.F. Lesgaft.

Vishibuti, D., Yovanovi, A., Milenti, K. (2004). Theory and methods of physical education. Beograd: Vytcsha Shkola za Sportske Trenere.

Zhamperisova, K.K., Dosybaeva, G.K. (2010). On the quality of training specialists with higher education. Bulletin of the West Kazakhstan Humanitarian Academy, 1(12), 7-13. 